\title{
Variations in Plasmid DNA Sequences Present in Crown Gall Tumour Lines
}

\author{
By ANN G. MATTHYSSE \\ Department of Botany, University of North Carolina, Chapel Hill, \\ North Carolina 27514, U.S.A.
}

(Received 27 May 1977)

\section{INTRODUCTION}

Extracellular infections of wounded dicotyledonous plants by the Gram-negative bacterium Agrobacterium tumefaciens (Smith \& Townsend) Conn result in the transformation of normal plant cells to tumour cells. These crown gall tumour cells will continue to grow autonomously in the absence of the bacterium (Braun, I943). Virulent strains of A. tumefaciens contain a large plasmid ( $120 \times 10^{6}$ molecular weight; Zaenen et al., 1974). The presence of this plasmid is correlated with the virulence of the bacterium (Van Larebeke et al., 1974). Bacteria which have lost the plasmid are avirulent and regain virulence when the plasmid is reintroduced into them (Watson et al., 1975). One strain of crown gall tumour cells, Vinca rosea $\mathrm{v}_{\mathrm{A} 6}$, has been shown to contain DNA sequences complementary to more than $50 \%$ of the bacterial plasmid DNA (Matthysse \& Stump, 1976). In order to determine whether this tumour strain is unique, two other bacteria-free strains of crown gall tumours have been examined for the presence of DNA sequences complementary to plasmid DNA.

\section{METHODS}

Media. Agrobacterium tumefaciens strains $\mathrm{BP}$ and $\mathrm{B} 6$ were grown in minimal salts medium containing $\left(\mathrm{g} \mathrm{l}^{-1}\right): \mathrm{NH}_{4} \mathrm{Cl}, 5 ; \mathrm{NH}_{4} \mathrm{NO}_{3}, \mathrm{I} ; \mathrm{Na}_{2} \mathrm{SO}_{4}, 2 ; \mathrm{K}_{2} \mathrm{HPO}_{4}, 3 ; \mathrm{KH}_{2} \mathrm{PO}_{4}, \mathrm{I} ; \mathrm{MgSO}_{4} .7 \mathrm{H}_{2} \mathrm{O}$, 0.1 ; with $0.2 \%(\mathrm{w} / \mathrm{v})$ glucose and 50 to $100 \mu \mathrm{Ci}$ [methyl- ${ }^{3} \mathrm{H}$ ]thymidine $\mathrm{ml}^{-1}$ (Clowes \& Hayes, 1968). Vinca rosea crown gall tumour tissue culture cells were grown on unsupplemented White's medium (Wood \& Braun, 196I). Normal $V$. rosea tissue culture cells were grown on White's medium supplemented with $\left(\mathrm{mg} \mathrm{l}^{-1}\right): \alpha$-naphthalene acetic acid (NAA), I; kinetin, 0.5; asparagine, 200; glutamine, 200; meso-inositol, 100; AMP, 100; GMP, 100 (Wood \& Braun, I96I). Normal tobacco was grown on Murashige \& Skoog's (1962) medium supplemented with $5 \mathrm{mg} \mathrm{NAA} \mathrm{l}^{-1}$ and $\mathrm{I} \mathrm{mg}$ kinetin $\mathrm{l}^{-1}$. Bryophyllum tissue cultures were grown on Miller's medium (1961) containing $1 \mathrm{~g}$ citric acid $\mathrm{l}^{-1}$ and $2 \mathrm{mg} \mathrm{NAA}^{-1}$.

Organisms. Agrobacterium tumefaciens strain BP and $V$. rosea normal strain NV and crown gall tissue culture strain $\mathrm{V}_{\mathrm{BP}}$ were obtained from Professor A. Braun. Tissue cultures of normal Nicotiana tabacum were obtained from P. Wyman. Agrobacterium tumefaciens strain B6 and Bryophyllum crown gall tissue culture strain $\mathbf{B}_{\mathrm{B}}$ were obtained from Professor C. Miller.

Isolation of DNA. Plant cell DNA was extracted by the method of Kirby (1957) as previously described (Matthysse \& Stump, 1976). Purified DNA preparations in $0.1 \times$ SSC (saline sodium citrate, where $1 \times$ SSC contains $0.15 \mathrm{M}-\mathrm{NaCl}$ and $0.015 \mathrm{M}$-trisodium citrate) had $E_{260} / E_{280}$ ratios between I.75 and I.95. No RNA was detectable by examination of the supernatant from the base hydrolysis $\left(0.3 \mathrm{M}-\mathrm{KOH}, 18 \mathrm{~h}, 37^{\circ} \mathrm{C}\right)$ of $100 \mu \mathrm{g} \mathrm{DNA} \mathrm{ml} \mathrm{m}^{-1}$ for $E_{280}$.

Bacterial plasmid DNA was prepared as previously described (Matthysse \& Stump, 1976) or by CsClethidium bromide equilibrium density gradient centrifugation as described by Klein et al. (1975). Each of the strains used appears, from restriction endonuclease digestion patterns, to contain only one type of plasmid (Mandelkorn \& Matthysse, unpublished observation). The specific activity of the tritiated bacterial plasmid DNA ranged from $2 \times 10^{5}$ to $1 \times 10^{6}$ c.p.m. $\mu \mathrm{g}^{-1}$. Before use in hybridization reactions, both the plant and plasmid DNAs were degraded to a molecular weight of approximately $2 \times 10^{5}$ by a limited depurination reaction (McConaughy \& McCarthy, 1967). The DNA was dissolved in 0.1 M-sodium acetate $\mathrm{pH} 4.2$ and heated at $70^{\circ} \mathrm{C}$ for $33 \mathrm{~min}$. The $\mathrm{pH}$ of the solution was then adjusted to 12 with $\mathrm{NaOH}$ and the solution was heated at $50^{\circ} \mathrm{C}$ for $10 \mathrm{~min}$. It was then dialysed against $1.5 \times \mathrm{SSC}$. 
Hybridization reactions. DNA hybridization reactions were carried out in $\mathrm{I} \cdot 5 \times \mathrm{SSC}$ in sealed glass capillary tubes at $67^{\circ} \mathrm{C}$. The DNA was denatured by heating at $100^{\circ} \mathrm{C}$ for $15 \mathrm{~min}$. Total radioactive DNA was measured by trichloroacetic acid (TCA) precipitation at $4^{\circ} \mathrm{C}$ using bovine serum albumin as a carrier, followed by filtration on Whatman GF/C filters which were washed with $10 \%(\mathrm{v} / \mathrm{v}) \mathrm{TCA}$ and ethanol, dried, and counted in a liquid scintillation counter. Double-stranded radioactive DNA was measured by incubating the sample ( $20 \mu \mathrm{g}$ or less) with 2 units of Neurospora crassa endonuclease (Miles Laboratories, Elkhart, Indiana, U.S.A.) in $1.5 \times \mathrm{SSC}$ at $37^{\circ} \mathrm{C}$ for $30 \mathrm{~min}$ to degrade single-stranded DNA. The remaining doublestranded DNA was precipitated by TCA, collected by filtration on GF/C filters and counted.

The rate of renaturation of a known concentration of radioactive bacterial plasmid DNA was determined in the presence and absence of non-radioactive DNA from crown gall tumour cells. The concentration of radioactive bacterial plasmid DNA in these reaction mixtures was small, in order that the point at which the change in slope of the reactions occurred would be as distinct as possible. The rate of renaturation of the plasmid DNA alone was unaffected by the addition of $300 \mu \mathrm{g}$ normal tobacco DNA ml${ }^{-1}$ or $800 \mu \mathrm{g}$ normal $V$. rosea DNA ml ${ }^{-1}$. Under the conditions used I $\mu \mathrm{g}$ plasmid DNA ml ${ }^{-1}$ renatures with a slope of $0.01 \mathrm{~h}^{-1}$

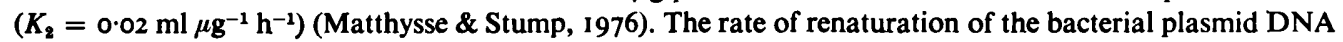
sequences in the mixtures of plasmid DNA with tumour cell DNA is determined by the concentration of DNA sequences complementary to plasmid DNA in the tumour since the radioactive bacterial plasmid DNA is present at too low a concentration to renature at a significant rate by itself.

The data were analysed using the method of Sharp, Pettersson \& Sambrook (1974) and the equation (Gallimore, Sharp \& Sambrook, 1974):

$$
\frac{C_{0}}{C}=\frac{K_{2} C_{0}(\mathrm{I}+r) t}{2}+\mathrm{I}
$$

where $C_{0}$ and $C$ refer to the concentrations of total and single-stranded radioactive plasmid DNA respectively, $K_{2}$ is the second order rate constant, $t$ is time, and $r$ is the ratio of non-radioactive complementary DNA sequences to the radioactive sequences. If only a fraction of the radioactive DNA sequences is contained in the added non-radioactive DNA, then the rate of renaturation will be increased only until these sequences have renatured (Gallimore et al., 1974). The value of $C_{0} / C$ at which the slope of $C_{0} / C$ against time changes will be the inverse of one minus the fraction of the radioactive DNA sequences present in the non-radioactive DNA. Thus, if $30 \%$ of the plasmid sequences are present in the tumour cells the slope of $C_{0} / C$ versus $t$ will change at $C_{0} / C=\mathrm{I} / 1-0.3=1.43$.

\section{RESULTS AND DISCUSSION}

The results of hybridization reactions between ${ }^{3} \mathrm{H}$-labelled plasmid DNA derived from two strains of $A$.tumefaciens (B6 and BP) and crown gall tumour cell DNA from tumours induced by these strains (Bryophyllum $\mathrm{B}_{\mathrm{B} 6}$ and $V$. rosea $\mathrm{V}_{\mathrm{BP}}$, respectively) are shown in Fig. I. Each of the tumour lines appears to contain some DNA sequences complementary to bacterial plasmid DNA. The slope of the renaturation curves of the two tumour lines indicates that between $0 . \mathrm{I}$ and $0.2 \%$ of the tumour cell DNA from each of the lines studied was complementary to plasmid DNA. [It is difficult to convert this number into an amount of plasmid DNA per diploid plant cell genome as many of these tissue culture cells are aneuploid (Matthysse, unpublished observations).] However, the percentage of the total plasmid DNA sequences present varies with the tumour line: $\mathbf{B}_{\mathrm{B} 6}$ appears to contain about $40 \%$, and $\mathrm{V}_{\mathrm{BP}}$ about $15 \%$. This is in contrast to the crown gall tumour line previously studied, $V$. rosea $\mathrm{v}_{\mathbf{A} \text {, }}$, which appeared to contain more than $150 \%$ of the bacterial plasmid DNA sequences (Matthysse \& Stump, 1976).

The variation in the percentage of the plasmid DNA sequences present in the tumour lines does not appear to correlate with either the species of plant or the length of time the tumour has been in tissue culture. The two lines of $V$. rosea studied differ, $\mathrm{v}_{\mathbf{A} \boldsymbol{B}}$ having more than $50 \%$ (Matthysse \& Stump, 1976) and $\mathrm{V}_{\mathrm{BP}}$ having only about $15 \%$ of the plasmid DNA sequences present. The strains studied vary greatly in the length of time since they were originally transformed and placed in tissue culture. The Vinca strains have been in culture since about 1960 (A. Braun, personal communication); and the Bryophyllum strain has been in culture less than I year (C. Miller, personal communication). Thus the differing amounts of plasmid DNA present do not appear to represent a gradual loss of plasmid DNA sequences with time in tissue culture. 


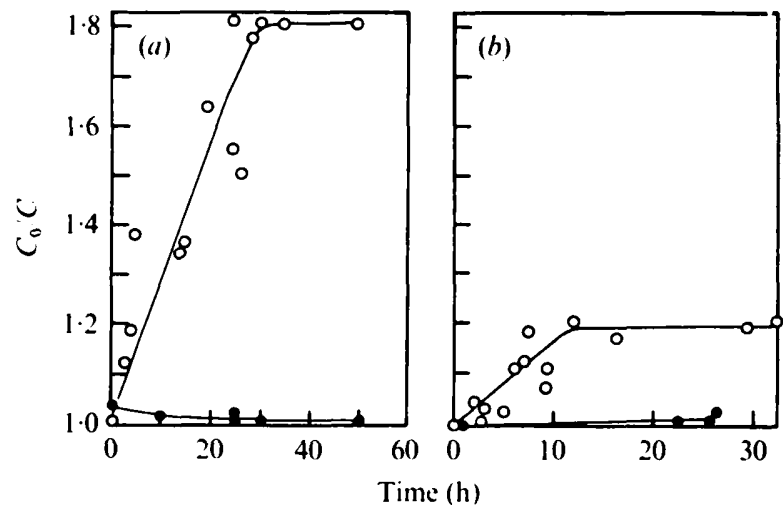

Fig. I. Renaturation of ${ }^{3} \mathrm{H}$-labelled $A$. tumefaciens plasmid DNA in the presence and absence of crown gall tumour cell DNA. (a) Renaturation of $0.04 \mu \mathrm{g} A$. tumefaciens $\mathrm{B} 6$ plasmid DNA ml ${ }^{-1}$ : , alone; $\bigcirc$, in the presence of $800 \mu \mathrm{g} \mathrm{Bryophyllum} \mathrm{B}_{\mathrm{B} 6}$ tumour DNA ml $\mathbf{m}^{-1}$. (b) Renaturation of $0.04 \mu \mathrm{g} \mathrm{A}$. tumefaciens BP plasmid DNA ml-1: 0 , alone; $\bigcirc$, in the presence of $300 \mu \mathrm{g} V$. rosea $\mathrm{V}_{\mathrm{BP}}$ tumour DNA $\mathrm{ml}^{-1}$.

This situation may be similar to adenovirus-induced tumours in animal cell cultures in which the incorporation of only a small fraction of the virus genome (about $5 \%$ ) is required for tumour formation (Graham, van der Eb \& Heijneker, 1974). However, different cell lines transformed by adenovirus-2 contain amounts of virus DNA varying between I 4 and $49 \%$ of the total virus DNA (Gallimore et al., 1974; Sharp et al., 1974). Thus more than the minimum amount of virus DNA necessary for transformation is maintained in some of these cell lines.

Similarly only a small portion (15\% or less) of the Agrobacterium plasmid may be required for transformation, but some cell lines may maintain more than this minimum fragment of the plasmid DNA.

The evidence presented above supports the hypothesis that $A$. tumefaciens induces tumours by transferring plasmid nucleic acid from the bacterium to the plant cells. Apparently the maintenance (and possibly transfer) of the entire $A$. tumefaciens plasmid is not necessary for the maintenance of the crown gall tumour.

This research was supported by grant number CA I 8604 , awarded by the National Cancer Institute, DHEW.

\section{REFERENCES}

Braun, A. C. (1943). Studies on tumor inception in the crown-gall disease. American Journal of Botany 30, 674-677.

Clowes, R. C. \& Hayes, W. (1968). Experiments in Microbial Genetics, pp. 184-185. New York: John Wiley.

Gallimore, P. H., Sharp, P. A. \& Sambrook, J. (1974). Viral DNA in transformed cells. II. A study of the sequences of adenovirus 2 DNA in nine lines of transformed rat cells using specific fragments of the viral genome. Journal of Molecular Biology 89, 49-72.

Graham, F. L., van der Eb, A. J. \& Heijneker, H. L. (1974). Size and location of the transforming region in human adenovirus type 5 DNA. Nature, London 251, 687-69I.

KIRBY, K.S. (1957). Isolation of deoxyribonucleic acid. Biochemical Journal 66, 495-503.

Klein, G. E., Jemison, P., HaAk, R. A. \& MatTHYSSE, A. G. (1975). Physical evidence of a plasmid in Rhizobium japonicum. Experientia 31, 532-533.

MatThysse, A. G. \& Stump, A. J. (1976). The presence of Agrobacterium tumefaciens plasmid DNA in crown gall tumour cells. Journal of General Microbiology 95, 9-16.

McConaughy, B. L. \& McCarthy, B. J. (1967). The interaction of oligodeoxynucleotides with denatured DNA. Biochimica et biophysica acta I49, $180-189$.

Miller, C. O. (196I). A kinetin-like compound in maize. Proceedings of the National Academy of Sciences of the United States of America 47, 170 174.

Murashige, T. \& Skoog, F. (1962). A revised medium for rapid growth and bioassays with tobacco tissue cultures. Physiologia plantarum r5, 473-497.

Sharp, P. A., Pettersson, V. \& Sambrook, J. (1974). Viral DNA in transformed cells. 1. A study of the 
sequences of adenovirus 2 DNA in a line of transformed rat cells using specific fragments of the viral genome. Journal of Molecular Biology 86, 709726.

Van Larebeke, N., Engler, G., Holsters, M., Van DER ElsaCker, S., ZaENen, I., SCHILPEROORT, R. A. \& Schell, J. (1974). Large plasmid in Agrobacterium tumefaciens essential for crown gall-inducing ability. Nature, London 252, 169170.

Watson, B., Currier, T. C., Gordon, M. P., Chilton, M. D. \& Nester, E. W. (1975). Plasmid requirement for virulence of Agrobacterium tumefaciens. Journal of Bacteriology 123, 255-264.

WoOd, H. N. \& BraUN, A. C. (196I). Studies on the regulation of certain essential biosynthetic systems in normal and crown gall tumor cells. Proceedings of the National Academy of Sciences of the United States of America 47, 1907-1913.

Zaenen, I., Van Larebeke, N., Teuchy, H., VaN Montagu, M. \& Schell, J. (1974). Supercoiled circular DNA in crown-gall inducing Agrobac. terium strains. Journal of Molecular Biology 86, 109-127. 